\title{
AFRICAN ETHICS AND PARTIALITY
}

\author{
Motsamai Molefe \\ University of KwaZulu-Natal \\ Molefem@ukzn.ac.za
}

\section{ABSTRACT}

This article explores the question whether African ethics is best captured in terms of partiality or impartiality. I take one influential instance of a defence of impartiality in the African tradition, sympathetic impartiality, by Kwasi Wiredu, and I use it as a foil to represent African ethics. I argue that impartiality, as represented by Wiredu, fails to cohere with moral intuitions characteristic of African moral thought, namely: the high prize usually accorded to the family, veneration of ancestors and the notion of personhood. I merely touch on the first two intuitions; I base my argument largely on the normative concept of personhood that is considered to be definitive of African moral thought.

Keywords: African ethics; partiality; impartiality; personhood

\section{INTRODUCTION}

One of the central debates in moral philosophy is the question whether morality is definable either in terms of partiality or impartiality (Cottingham 1986; Singer 1979; Wolf 1992). To date, African scholars have not made it their project to critically and extensively reflect on the nature of African ethics in terms either of partiality or impartiality. 'Partiality' is the view that we have immediate or stronger moral obligations to our own personal ties or special relationships, like friends and family, than we have to strangers (Cottingham 1986: 357; Metz 2011). Another way to make sense of partiality is in terms of agent-relativity (McNaughton and Rawling 1992:

\section{UNISA}


526). ' 'Impartiality' is the claim that we owe equal moral consideration to all moral patients without any consideration to the so-called special relationships; a moral agent is expected, on this view, to dispense moral goods from an indifferent, impersonal, or what is sometimes called an "ideal point of view" (Jollimore 2014). Another way to make sense of impartiality is in terms of agent-neutrality (McNaughton and Rawling 1992: 526). ${ }^{2}$ Typically, influential African moral theories - Kwasi Wiredu's "sympathetic impartiality" and Kwame Gyekye's description of African ethics in terms of "supererogationism", or so I read them, construe African ethics to be best interpreted in terms of impartiality (Gyekye 2010; Wiredu 1992: 193-206). ${ }^{3}$ In this article, I argue that African ethics is best understood in terms of partiality rather than impartiality. ${ }^{4}$

To support my argument, I invoke three moral intuitions; but I will mainly focus on one to make my case. I observe that the high price usually attached to family; the veneration of ancestors and the normative notion of personhood recommend partiality rather than impartiality. My argument is that if these moral intuitions are some of the crucial moral features that characterise African moral thought, then African ethics is best conceived in terms of partiality. But, on the main, for my defence of African ethics as partialist, I will focus on the moral notion of personhood that is generally accepted to be central to African moral thought (Menkiti 1984; Wiredu 2008). I invoke one influential moral theory in the African tradition, namely "sympathetic impartiality", as foil to represent African ethics so as to facilitate a meaningful philosophical debate between impartiality and partiality in the African tradition.

The use of the phrase "African ethics", before I proceed, may strike some as controversial and thus requiring some clarification with regards to how I will be using it in this article. I use the notion 'African' in the phrase African ethics to refer to general and salient moral intuitions that are considered to be salient below the

1 One is acting on agent-relative reasons or aims if there is an essential reference to one within those reasons and aims (McNaughton and Rawling 1992). Suppose one asks a parent why s/he is paying his/her daughter's university fees. A reasonable answer, which captures agent-relative reasons, would be: "she is $m y$ daughter".

2 One is acting on agent-neutral reasons or aims if she merely wants to help everyone irrespective of who they are and without regards to any relations she may be enjoying with them (McNaughton and Rawling 1992: 526).

3 I am aware that Metz's $(2009 ; 2011)$ observes that African ethics is definable by partiality, but he does not do so by appeal to the notion of ancestors and personhood like I do. Appiah also makes a case that African ethics is partialist (1998 - see list of references) but also does not appeal to the intuitions invoked here. My contribution introduces one or more features they do not consider to ground partiality, mainly the insight that the idea of personhood implies partiality.

4 I am here arguing that given what we have in the literature, the stock of moral intuitions that are prevalent below the Sahara and the anthropological data at our disposal, it appears that partiality better fits with these than impartiality. I leave it for another project to defend partiality in the African tradition by appeal to independent considerations that would convince a non-African. 
Sahara. It is in this light that usually scholars use this notion. For example, Gyekye, an influential African philosopher, contributes an encyclopaedic article titled "African ethics" and he describes this notion thus:

'African ethics' is used to refer both to the moral beliefs and presuppositions of the subSaharan African people and the philosophical clarification and interpretation of those beliefs and presupposition. (Bujo 2001; Gyekye 2010; see also Eze 2005; LenkaBula 2008; Louw 2004; Metz 2007; Wiredu 1992)

This understanding of the phrase "African ethics" defines it in terms of two facets. Firstly, it defines it by invoking commonly shared moral beliefs and presuppositions by people below the Sahara. Secondly, it refers to the intellectual reflections and deliberations on these moral intuitions. So, this definition does not presuppose that there is absolute agreement about African moral thought, but to mean that there are sufficient commonalities among the peoples below the Sahara that warrant and justify the use of this phrase to capture a body of work attempting to critically reflect on these (commonly) held moral beliefs.

Again, it is crucial that I justify why I use and select Wiredu's moral theory to represent African ethics. I do so for several reasons. Firstly, I follow the example of other African scholars, specifically Okeja, who sets himself the task of "analysing global ethic from an African perspective of ethics in African philosophy. The goal is to use this tradition of philosophy as a comparative ground for normative justification that is sought. Basically, this will be done by elaborating on the ethical thoughts of Kwasi Wiredu whose theory of sympathetic impartiality is akin to the Golden rule principle" (Okeja 2013: XIV [own emphasis]). Here, Okeja's aim is to use insights from an African moral tradition to contribute to discourses on global ethics. Interestingly, however, he uses Wiredu's sympathetic impartiality to represent the tradition of African philosophy since it has the pertinent moral properties relevant for his project. Similarly, I also invoke Wiredu's moral theory of sympathetic impartiality to represent the tradition of African moral philosophy, since he defends the thesis that African ethics is best understood in terms of impartiality. Further, there is a tendency among African scholars to reflect on a specific African culture but draw philosophical reflections that they refer to as "African" rather than merely "Akan". For example, Wiredu's (1992: 192) article reflecting on the Akan culture is titled "Moral foundations of an African culture".

Further, so far as I am aware, no one specifically defends a moral theory in the African tradition that explicitly invokes the notion of impartiality like Wiredu does. The idea of partiality/impartiality does not seem to be a relevant consideration for other moral thinkers in the tradition (Bujo 2001; Shutte 2001). Some appear to be confused on the matter, for example, Gyekye's defence of "moderate communitarianism" appears to anticipate partiality (Gyekye 1992); in some of his articulations, however, he explicitly embraces impartiality, though he does not give 
an argument for it (Gyekye 2004). Thus, I focus on Wiredu's moral theory since it has the relevant problematic feature of impartiality as a defining feature of his principle of right action.

This article proceeds as follows. Firstly, I define the notions of partiality and impartiality, and subsequently introduce the reader to a debate about whether morality is best characterised in terms of partiality or impartiality in the Western tradition. I do so mainly to familiarise readers with this debate by drawing from the Western context; mine is not a comparative project. My aim, if this partiality and impartiality debates matters at all, as I suppose it does, is to point out that African ethics should be understood in terms of partiality. Secondly, I present Wiredu's "sympathetic impartiality" as an instance of a defence of impartiality in the African moral tradition. In the third section, I present some prima facie evidence from an African tradition that points towards partiality, specifically the high regard accorded to family structure and ancestor veneration. I subsequently show that a commitment to a normative conception of personhood qua a good person endorses partiality the point here is to show that impartiality does not cohere with this (and other two) central tenet(s) of African moral thought. I appeal to this normative notion of a person to demonstrate partiality, since it is dominantly taken to be characteristic of African moral thought, even by Wiredu (Dzobo 1992; Gyekye 1992; 1997; Ikuenobe 2006; Menkiti 1984; 2004; Wiredu 1992; 1999; 2008). I begin by providing a context for my discussion by familiarising the reader with the partiality-impartiality debate from a Western context. I do so precisely because I indicated above that there is no body of work that has critically reflected on this debate in an African tradition.

\section{PARTIALITY AND IMPARTIALITY IN MORAL DISCOURSE}

One of the key debates in moral philosophy is the question: What is the relationship between morality and im/partiality? Some scholars have pointed to the tendency for morality to be essentially defined in terms of impartiality (Cottingham 1981: 83; Wolf 1992: 243). By impartiality they do not mean, at least on the face of it, something that is entirely unintuitive. They mean the idea that the interests of all should count and that they should count equally. Should a moral theory continuance the claim of partiality, then it cannot be properly called "moral" since it will be characterised by favouritism. One such instance of impartiality is represented well by Rachels and Rachels (2010: 10) in their introductory book on moral philosophy. They define morality in terms of what they call "Minimum conception of morality":

As a start, we note two main points: first, moral judgements must be backed by good reasons; and, second, morality requires the impartial consideration of each individual's interests. (Rachels and Rachels 2010: 10) 
This definition of morality has two components, the first: morality is construed as a rational enterprise; and, the second, impartiality. With regards to rationality the idea is that moral arguments should be resolved relative to the weight of evidence (reasons) supporting the claims in question. With regards to impartiality it appears that Rachels and Rachels are arguing that there is no rational basis to discriminate among persons, given that they are all equally human and as such our treatment should manifest equal regard for their interests and welfare (Wolf 1992: 243). Another interesting way of making sense of impartiality, according to Singer, one influential proponent of this view, is in terms of what he calls the "Impartialist thesis" - the claim that "ethics requires us to go beyond the 'I' and 'you' to the universal law, the universalisable judgement, the standpoint of the impartial spectator or ideal observe" (Singer 1979: 11). I will leave out the problematic aspects of this quotation, it suffices to observe that Singer equates ethics with what he calls "the standpoint of an impartial spectator" i.e. "the special point of view that has to be taken when considering moral issues" (Musschenga 2005: 2). The idea that follows from here is that morality requires one to abstract, as it were, from a personal point of view or self-interest, which is taken to be non-moral or pre-ethical, and to occupy a moral standpoint (Wolf 1999: 204-206), which is essentially characterised by impartiality, wherein the interests of all are taken as equal.

This kind of approach to ethics calls our attention to Godwin's (1973) famous case of the bishop and the maid. Godwin insists that if the two are caught in fire, and we can only save one, then ours is to impartially consider whose saving will maximise welfare. Facts about who they are and what they may possibly mean to one may be interesting, but are morally irrelevant - welfare maximisation is all that matters in the moral sphere. Famously, Godwin goes on to ask a rhetorical question about what magic is there in the fact that one is my mother or wife or even daughter (Godwin 1973: 41-42). ${ }^{5}$ What emerges saliently from this approach to ethics is that a self, her projects and special relations are rendered irrelevant in the moral domain; morality requires one to be neutral and impartial (Jollimore 2014). I take a view that necessarily considers self-interest to be a moral defect to be problematic. It is not clear to me that to act from self-interest is obviously wrong or morally irrelevant ${ }^{6}$,

5 It is important that I clarify that, here, impartiality does not require that people be should be given equal treatment, rather it demands that people be treated as equals (Jollimore 2014). To "treat people as equals" entails a response that is informed by what a person morally deserves. If, for example, one has a person who has stolen some money and a person who has killed many people, it would be unfair to give such people equal treatment, say give them the same jail sentence; but, it will be fair to treat them as equals, by way of dispensing a jail sentence relative to what they deserve.

6 Cottingham (1981: 84-86) provides an illuminating distinction between self-interest and selfishness, and how self-interest is related to morality and impartiality. 
unless one acts under an influence of some theory about a "self". ${ }^{7}$ For example, if one takes a view similar to that of Hobbes who considers personal interests or a "self" to be essentially characterised only by self-absorbing self-interest that could lead to one man turning (warring) against another, then a view similar to that of Singer makes sense (see Wolf 1999).

One argument for impartiality proceeds by way of problematising the tendency by human beings to generally manifest concern and sympathy for their own families and friends. This concern is expressed thus:

[that] the 'general object' of morality, appreciation of which may enable us to understand the basis of moral evaluation, is to contribute to betterment - or non-deterioration - of the human predicament, primarily and essentially by seeking to countervail 'limited sympathies' and their potentially most damaging effects...[the aim of morality is]...to expand our sympathies, or, better, to reduce the liability inherent in their natural tendency to be narrowly restricted. (Warnock 1971: 26)

The argument begins by pointing to some limitations with regards to human nature, or a tendency to show partiality to our families and friends. The aim of morality is to expand the scope of our sympathies to reach out to humanity as a whole so far as is humanly possible, and the reason for this is that all of us are human and are equal in that status. And, since there is no non-arbitrary basis to discriminate among human beings; it should follow that a manifestation of "limited sympathies" is an instance of a moral defect, which might have "damaging effects" to our commitment to the betterment of humanity as a whole, therefore morality must be both universal and impartial.

On the other hand, partialists defend the intuition that special relationships like family and friends problematise attempts to define morality strictly in terms of impartiality. As Wolf observes

... many have called attention to the fact that relationships of friendship and love seem to call for the very opposite of an impartial perspective. Since such relationships unquestionably rank among the greatest goods of life, a conception of morality that is in tension with their maintenance and promotion is unacceptable. (Wolf 1992: 243)

Common sense morality highly ranks special relationships like family and friends. These relationships are special precisely because of their exclusiveness in terms of the resources and attention we usually expand on them, that we do not for any other non-special relation (Cottingham 1981: 89). Typically, we are propelled by a moral burden to do more for our special relationships; that we do not feel similarly for other relationships with strangers, for example. What argument has been proffered to ground these partialist considerations?

7 Wolf (1999: 203-223) problematises the idea of a "moral point of view" in an illuminating way, and shows its problems. She further recommends that we free ourselves from its influence and its simplistic implication about our "personal point of view". 
One famous line of defence for partiality is that the special relations we have with our own projects, friends, families and colleagues are an essential part of our identity, a distinctive self of who we are (Cottingham 1986; Liew 2008). If morality by definition demands that we distance ourselves from all these, it is not only that it is too demanding, but it also seems to be demanding the psychologically impossible (Williams 1974: 198). This objection generally goes by the name of "alienation": the idea that impartiality is asking individuals to sacrifice not only the people and things we value; but, more, it requires us to sacrifice who we are in the altar of being "moral" (Williams 1974: 198). The force of this objection is that even if it were psychologically possible to do so, it seems to be morally defective to do so. This same concern about morality qua impartiality is best expressed by Wolf when she says: "The problem is not that impartiality is too closely or centrally identified with morality, but that morality as a whole is being expected to do too much" (Wolf 1992: 243). If morality is defined in terms of impartiality, morality will consume all of one's life - one will have no life that they can call their own in an interesting way; rather, one will be a slave of morality.

It is, however, not within the scope of this paper to exhaust this debate or to give a critical engagement of what has been presented thus far: my aim was to give the reader a rough sense of this debate. I proceed now to discuss Wiredu's principle of sympathetic impartiality as a foil for African ethics.

\section{WIREDU'S SYMPATHETIC IMPARTIALITY}

By "moral theory", here, I specifically refer to a principle of right action. As such, I focus on Wiredu's principle of right action qua sympathetic impartiality; my aim, I emphasise, is to illuminate impartiality as the defining feature of Wiredu's moral principle. I begin by noting Wiredu's definition of morality:

...what is good in general is what promotes human interests. Correspondingly, what is good in the more narrowly ethical sense is, by definition, what is conducive to the harmonization of human interests. (Wiredu 1992: 194; see also Wiredu 2008: 334)

I will not here concern myself with what Wiredu means by either "the good in general" or "the more narrowly ethical sense"; I do not clarify this distinction since it is not crucial for my purposes in this article. What is clear, however, according to Wiredu, is that morality can be captured in terms of "promoting human interests" or "what is conducive for harmonising human interests". In another place, Wiredu comments:

Every Akan maxim about the specifically moral views that I know...postulates the harmonization of interests as the means, and the securing of human well-being as an end, of all moral endeavour. (Wiredu 1996a: 65) 
What then becomes clear is that "harmonisation of interests" is the process or means required for achieving the good, which is human well-being. One way to make sense of human well-being, the good, is in terms of the intrinsic good, that which is good in and of itself - and, the harmonisation of human interests is an instrumental good, that which is useful for bringing about certain outcomes. To make better sense of this theory we need to clarify two critical questions with regards to the idea of "harmonisation of human interests".

Firstly, why do human interests need to be harmonised and what does that have to do with morality? Secondly, what is the procedure or process that informs this harmonisation of human interests?

I start with the first question: "Why do human interests need to be harmonised?" To respond to this question, Wiredu uses the art motif of a crocodile with one stomach and two heads. Wiredu interprets this art motif to imply the following about morality:

...although human beings have a core of common interests, they also have conflicting interests that precipitate real struggles...the aim of morality...is to harmonize those warring interests through systematic adjustment and adapting. (Wiredu 1992: 197)

In another place, he observes that "Human beings have common as well as conflicting interests. Co-existence in society requires some adjustment or reconciliation of these interests" (Wiredu 1996a: 41). Reasonably, the moral view emerges as a reality to safeguard the continuing or to avoid the collapsing of the human society; as such, some kind of harmonisation of human interests is decisive in a moral sense. That is: without this harmonisation of conflicting human interests, we would retreat to something like the Hobbesian "state of nature" wherein each one would turn (war) one against another in pursuit of their own interests; as such, the harmonisation of human interests is plausibly identified as moral. It is for this reason that one of the things that are deemed most immoral in Wiredu's moral view is selfishness - as it typifies the possible reification of "the state of nature" which functions by being indifferent to others' needs and interests (Wiredu 1996a: 64).

Secondly, Wiredu is also lucid with regards to the principle that is to serve as a guiding moral compass, without which "the survival of human society in a tolerable condition would be inconceivable" (Wiredu 1996a: 29). By this, we are seeking for a principle through which the harmonising of human interests would be effected or a procedure that would conduce towards welfare. Wiredu calls this principle "sympathetic impartiality", which he understands to be tantamount to the golden rule (Wiredu 1992: $194 \&$ \& 198; 1996a: 29, $41 \&$ 170). It is also important to note that Wiredu is indifferent with regards to whether one formulates the golden rule negatively (do not treat others in ways you would not want them to treat you) or positively (so act towards others in ways you would want them to act towards you) (Wiredu 1992: 198; Wiredu, 1996a: 31, 41). 
As noted above, Wiredu equates the golden rule in its different formulations to his principle of sympathetic impartiality (Wiredu 1996a: 170). Wiredu informs us that the principle of sympathetic impartiality requires us to "be willing to put oneself, as the saying goes, in the shoes of others when contemplating an action" (Wiredu 1996b: 237). At the heart of this ethical principle are the two concepts, sympathy, which Wiredu describes "as the root of all virtues" (1996a: 71), and impartiality, which I understand to reflect the moral position one must occupy when making a moral decision. Or, as aptly captured by Fayemi (2010: 29): "Sympathetic impartiality represents a fusion of impartiality and sympathy: the impartiality is what the moral rules embody, and the sympathy is what the moral motivation evinces." In other words, a decision is not moral unless it is characterised by impartiality with regards to considering the interests of others, and this consideration must also be characterised by the root of all virtues, sympathy. It appears that sympathetic impartiality is also "agent-neutral", that is, moral decisions must not proceed from any locus of focus; a moral agent must be indifferent and detached, in some sense, from herself and special relationships, when dispensing the good (MacNaughton and Rawling 1992: 836).

To exemplify how this principle of right action works, I appeal to this passage by Wiredu:

However, the rule in question is, most assuredly, not a moral rule and not regarded as such by the Akans. Any Akan will tell you that it is...[a custom]. But though it is a custom, it can, like anything else in the world, be evaluated from a moral standpoint. When it is subjected to this test, it is, of course, found wanting. Why so? Because the custom would seem to run counter to the principle of sympathetic impartiality: Would the king himself welcome an identical treatment in an exchange of stations? Most likely not. It appears that most people did their best to escape the honor of serving their kings under such metaphysical conditions. (Wiredu 1996b: 241)

In this passage, the custom that Wiredu is considering involves that in the event that a king dies, his vassals are killed so as to accompany him to the afterlife. Since it is a custom, it can be subjected to moral scrutiny to establish its validity, and to assess this custom we apply sympathetic impartiality. Wiredu, on his part, supposes that if a king impartially puts himself in the shoes of a vassal, in all likelihood he would not want to be killed, therefore the custom in question is invalid. I will not here evaluate the merit of this moral account, I wish however to emphasise the central role played by the notion "impartiality" in determining whether an action is right or wrong.

So, according to Wiredu, we cannot evaluate the moral status of an act, i.e. whether it is right or wrong, unless we include the moral facet of impartiality - the property of impartially plays a crucial role in defining morality. In the above example, the special relationship between a king and his vassal becomes morally irrelevant in considering what is morally right. The interests of all qua merely being human and what is required for them to function ordinarily, takes paramount importance. The 
king must strip himself of his status and the vassal the same, since these are not relevant moral considerations; and both must stand on a moral plain definable only by an equalising standpoint of impartiality. On this moral platform, the "king" must put himself in the shoes of a "vassal" and he must deliberate whether he would welcome the prospect of being killed: if his heart is not defective, then he will not want to be killed, therefore the "vassal" should not be killed. I will not deal with the obvious problems of this principle; I just hope the reader took cognisance of the primacy of the notion of impartiality in defining the entire moral terrain. I hope the reader also observed how special relationships and their attendant obligations lose their usual moral relevance in this moral scheme; as in the fact that one is a "king" usually implies a high degree of respect and special attention and the idea of being a "vassal" assigns particular responsibilities towards the king - but all that is rendered irrelevant in the moral domain.

I hope the reader can realise how Wiredu's principle of sympathetic impartiality makes impartiality a defining feature of morality. This feature requires the equalisation of all moral patients without regard to certain special features like family and friendship. I proceed below to invoke evidence that supports partiality.

\section{PARTIALITY AND AFRICAN MORAL THEORY: FAMILY, ANCESTORS AND PERSONHOOD}

Above, I discussed Wiredu's moral theory; and I showed how it marries the idea of morality to the idea of impartiality. Below, I invoke three aspects of African culture (moral intuitions) which recommend partiality as more consistent with an African moral thought, namely: 1) the high regard accorded to the family; 2) ancestor veneration; and 3) the normative concept of personhood qua a good person. I will not elaborate on all of these cultural items to make my argument; to build a strong case it suffices that I appeal to the notion of personhood, which is a central feature of an African moral thought. If impartiality will prove not to cohere with this notion of personhood, that will be enough ground to reject it. However, for the sake of a non-African audience, I will give a brief discussion of the other two aspects of African culture that also endorse partiality: high regard for the family and ancestor veneration.

I begin with the high regard that is usually accorded to the family in the African tradition. It is interesting to note that the family is reported as the best school for moral education (Appiah 1998; Wiredu 1996b: 248). It is also interesting to note that many African scholars articulate their moral theories in light of analogies drawn from how a family works or ought to work (Behrens 2011: 65-66; Metz 2007: 337; Oruka and Juma 1994: 124). For example, Shutte (1993: 50) states: "Perharps the best model for community in the African community is the family." In another place Shutte (2001: 
29) observes that a family is seen in the African tradition as intrinsically good, i.e. it is good in and of itself. Further, Ramose, an expert of Ubuntu, comments:

According to this understanding of the family, it is unethical to withhold or to deny botho/ ubuntu towards a member of the family, in the first place, and the community at large. In other words, charity begins at home [own emphasis]. (Ramose 2003: 386)

This observation by Ramose interestingly informs us that Ubuntu as a moral theory demands that she prioritises their extant relations, specifically, her own family, before she can extend kindness to a wider society. This prioritisation is explicitly captured by the phrase "in the first place". So, according to Ramose (2010), in our deliberation and action we should see it as our first responsibility to respond to the plight and needs of our special relationships before attending to strangers or society at large. This, on the part of Ramose (2010), is a statement that endorses partiality.

In another place, Ramose introduces the idea of partiality by using the idea of permeable boundaries since he is opposed to what he calls "bounded reason". He states: "Thus motho ke motho ka batho is the maxim that prescribes permeable boundaries" (Ramose 2003: 330). It is interesting to note whatever else this comment might amount to. Before it does that, it begins by validating boundaries between those within the circle of special relationships and those outside of them, thus tacitly affirming partiality; but, insightfully, he further informs us that the boundaries in question are permeable allowing for the of extension of Ubuntu to those who would ordinarily be considered "outsiders". In other words, one is urged to avoid moral myopia and parochiality by thinking that one's partialist considerations exhaust what morality is all about. A moral agent must recognise that she is not only her own person and a member of a family; moreover, she is also a member of different communities: her tribe, nation, country, continent and the world. It is for this reason that her moral sensitivity and sensibility must be as wide as the world, but all this "wide" moral responsibility must be interpreted from an agent's locus of focus, that is, from a perspective that is entirely her own. Simply put, though she has immediate duty to herself and family, and all things equal, she also has a duty to the community at large, but the strength of duties weakens further out of the circle she moves (Metz 2011).

It is not only the high price attached to the family that buttresses the view that African ethics is best read as partialist. Another interesting source for defending a partialist thesis is the ubiquitous practice of ancestor veneration among African peoples. I am not aware of any black-African peoples that do not believe in ancestors. Ramose (2010: 300) informs us that: "The concept of community in the African philosophy of Ubuntu (Botho - humanness) is comprised of three tiers, namely, the living, the living-dead ('ancestors') and the yet to be born. Life is salubrious and just if harmony prevails in these tiers of community." On this view, one can't sufficiently talk of an African community until they have spoken about ancestors 
or the living-dead. The "living-dead" are not gods, as in entities to be worshiped; strictly speaking, they are "persons" who have joined a supernatural realm of God because they have lived morally worthy lives (Menkiti 2004: 327). They continue to live as spiritual members of their own families and communities. Precisely because they are "persons", it is inappropriate and a sign of confusion to speak of "ancestor worship" - hence it is appropriate to talk of ancestor veneration/reverence (Menkiti 2004: 327).

One interesting aspect of ancestor veneration is that it functions within a partialist, family blood-line:

The other principal rule of action relates to ancestor worship. This is also based on the community of blood. It is a kind of worship that exclusively involves people of the same blood. And the main objective of the worship is to implore the help of the ancestors to send away all misfortunes that threaten their descendants [own emphasis]. (Kagabo 2004: 238)

The quote above rightly captures the idea that ancestor veneration typically functions within family blood relations, or, specifically, family in an extended sense. It is for this reason that some ancestor rituals only involve family members, or even if the whole community is involved some parts of the ritual would be held in private. In other words, each family has its own ancestors and they exclusively focus on their own ancestors. So, the ubiquitous celebration and veneration of ancestors, characteristic of African tradition, endorses partiality rather than impartiality.

I am invoking this idea of an ancestor because it is a moral term that signifies human beings (that have since died) that are moral exemplars, moral guardians and these beings are considered to reinforce morality in the African tradition (Gyekye 2010; Ramose 1999: 145).

Thus far, I have roughly discussed two aspects of African culture that somehow lend evidence to the effect that African moral thought is best interpreted as partialist. I proceed now to make my argument for partiality by considering the moral concept of personhood.

I argue to the effect that African moral thought is best construed in terms of partiality. One central notion in African morality is that of personhood. The notion of personhood admits three possible interpretations. Firstly, one can talk of personhood in a metaphysical sense, making descriptive claims about what constitutes a human being, a body, spirit and a soul, for example (Kaphagawani 2004: 332-342). Secondly, one can make claims about what qualifies some entity as worthy of our moral regard, since she has the relevant moral properties like rationality or sentiency (Dion 2000: 221). Thirdly, the notion of personhood could refer to the conduct of a moral agent whose actions are characterised by moral excellence (Metz 2007: 331). The last two senses are normative, the former is about a "moral patient" and what moral considerations are due to her, what we owe to some entity; and the latter is about a "moral agent", how one has conducted oneself relative to the pertinent moral 
norms and standards (Behrens 2013: 105-107). It is the third sense that is relevant in this article.

The notion of personhood is generally considered to be a fundamental or defining feature of African moral thought (Masolo 2010: 138; Wiredu 1992; 2004). It is also interesting to note that a dominant interpretation of African ethics is perfectionistic or a self-realisation account (Metz 2007: 331), that one has to realise one's true moral self. I am aware that Metz rejects this reading of African ethics, and defends a monistic deontological principle of friendship (Metz 2009: 49-52). I am, however, attracted to the pluralistic principle of right action qua self-realisation account defended by Lutz (2009: 316-317), which balances the idea of self-realisation (perfection) and communal goods. The central message from an African axiological context is that one has a duty, given the cultural resources provided by a community, to perfect herself and to discharge her duties to contribute to the good of the whole. With regards to this notion of personhood Gyekye states:

In Akan cultures, then, much is expected of a person in terms of the display of moral virtue. The pursuit or practice of moral virtue is held as intrinsic to the conception of a person. The position here may thus be schematized as: for my $p$, if $p$ is a person then $p$ ought to display in his conduct the norms and ideals of personhood. Thus, when a person fails to exhibit the expected moral virtues in his conduct, he is said not to be a person. (Gyekye 1992: 109)

It is not enough to be a human being; more is expected from African moral thought to be a good person. Metz corroborates this view when he observes that:

Personhood, selfhood, and humanness in characteristic sub-Saharan worldviews are valueladen concepts. That is, an individual can be more or less of a person, self, or human being, where the more one is, the better. The ultimate goal of a person, self, or human in the biological sense should be to become a full person, a real self, or a genuine human being, i.e. to exhibit virtue in a way that not everyone ends up doing. (Metz 2010: 83)

What captures my attention in the above quote is that as much as everyone is believed to have the moral capacity to exhibit some virtues, not everyone ends up doing so. In other words, some people fail to reach the status of being moral exemplars. In fact, in this regard Menkiti (2004: 326) states: "One conclusion appears inevitable, and it is to the effect that personhood is the sort of thing which has to be achieved, the sort of thing at which individuals could fail." Thus, a society will be composed of those who have failed to live a truly human life and those who have succeeded. And those who have failed will be blamed and those who have succeeded will be praised (Darwall 1977: 36-37). If it is true that this idea of one leading a genuine human life is an essential part of African moral thought, it appears to be taking us in a direction that is different from that of impartiality. One has to master the art of being human given one's social, economic, spiritual circumstances and challenges. It does not appear that there is time for one to abstract from oneself; rather, one is enmeshed with the 
reality of life in the world, as it were, to work hard to be the best one can be, morally speaking, given one's moral opportunities and challenges.

On the contrary, impartiality is calling an agent to depart from her personal view to a moral view, that is, to distance herself from who she is and the things that matter to her like friends and family, and occupy a moral point view. But, an African moral theory is calling one to be sensitive and responsive to day-to-day issues and challenges so as to develop a particular kind of moral identity steeped in a history that is characterised by moral victories. This partialist reading of personhood finds expression and support from a singularly unexpected source, Wiredu:

What, then, in its social bearings, is the Akan ideal of personhood? It is the conception of an individual who through mature reflection and steady motivation is able to carve out a reasonably ample livelihood for self, family, and a potentially wide group of kin dependents, besides making substantial contributions to the well-being of society at large. The communalistic orientation of the society in question means that an individual's image will depend rather crucially upon the extent to which his or her actions benefit others than him/herself, not, of course, by accident or coincidence but by design. The implied counsel, though, is not one of unrelieved self-denial, for the Akans are well aware that charity further afield must start at home. (Wiredu 1992: 200)

This passage is one which is supposed to shake Wiredu from his slumber of defending an untenable position of impartiality. It is obviously at odds with his moral principle of sympathetic impartiality. It is crucial to note that Wiredu appears to draw a distinction, in terms of priority, between one's "special relationships" (self and family) and "other people" to whom he refers as a "potentially wide group". Wiredu is very clear that one who becomes a good person is as a result of some personal exertion to improve one's own life. In this sense, a journey to moral perfection is a personal project, a partialist consideration, within the incubator of social context (Menkiti 2004: 326). It is important to note also that Wiredu appears to be suggesting that one owes immediate duty to self-development, then to his family and, if possible, one can benefit a wider group. Then the observation that "charity further afield must start at home" rubber-stamps the partialist reading of an African moral tradition - as much as one has a duty to the community at large, that duty must be interpreted within the prism of partiality, which prioritises one's personal projects of self-perfection, family, friends and so far as is possible, the community at large.

So, above, I have sketched three axiological resources with an African context that appear to be lending support to the idea that African ethics ought to be conceived in terms of partiality. One may reasonably object to this partialist reading of African ethics, by arguing that it renders it individualistic, and much of African ethics is communitarian. In this light Metz observes that one "finds contemporary African thinkers railing against Western 'brash competitiveness', 'single-minded commercialism', 'unbridled individualism', and 'morally blind, purely economic logic', instead tending to favour certain kinds of cooperatives" (Metz 2007: 326). 
Furthermore, Nkondo - commenting on Ubuntu - emphasises "the supreme value of society, the primary importance of social or communal interests, obligations and duties over and above the rights of the individual" (Nkondo 2007: 90). This position is sometimes captured as the ontological priority of the community over the individual (Menkiti 2004: 324; Nkondo 2007: 90). The objection here is that the idea of partiality leans towards an individualistic interpretation of African culture and moral thought, which is supposedly at odds with an African culture and moral thought that emphasise the slogan of a community first.

I think, first of all, it is important that we clarify two senses of the claim that African ethics is not individualistic, and much of the criticism in this direction conflates this distinction. On the one hand, one can use the notion of "individualism" to make a descriptive claim about how persons come to form their personal identities, and the role played by social relations (community) in this process (Neale and Paris 1990: 425-526). On the other hand, one can be making a claim about the location of moral value as internal in the individual (Behrens 2011: 18), and this in environmental ethics is typically contrasted with "holism", which locates value in the groups (Metz 2012: 388).

For the first kind of "individualism" one is making claims that are anthropological or about social-customary arrangements, specifically, contingent facts about how to organise society and formations of individual identities. ${ }^{8}$ In this light, Wiredu observes that African societies are "communitarian" in a sense that they prioritise what we owe to each other in terms of obligations (2008: 336). And, he is quick to remind us that the fact that some cultures are individualistic and some communitarian is a matter of degree, since all are ultimately interested in furthering individual interests, albeit differently (Wiredu 2008: 335).

The corrective and moderate understanding of community by Wiredu, I suspect, are strongly influenced by his colleague, Gyekye. Gyekye argues for what he calls "moderate communitarianism". His argument, first and foremost, is to reject what he calls "extreme communitarianism" insofar as it does have space for (individual) human rights - rights are things that belong to individuals qua individual (Gyekye 2007: 39). His moderate view balances the ideal of individuality (dignity) and that of community (common good) (Gyekye 1992: 113; 2007: 41). With regards to the latter it calls for a common good, and with regards to the former it demands that individuals be given certain rights that belong to them naturally. It further calls for enough space for individuals not to be wholly consumed by a community (Gyekye 1992: 114). I observe that Gyekye is correct to defend a space for individuals to pursue their own goals and for their rights to be protected, without jettisoning their social obligations.

8 I find the discussion of Neale and Paris (1990: 423-430) on "individualism" qua "contingently shared relations"; and communitarianism qua essentially shared relations, to be lucid. They are very clear that these are descriptive and not normative claims. 
I observe that the above comments inspired by moderate communitarianism are compatible with partiality. Moderate communitarianism admits that we have duties for promoting the common good, but it also equally recognises individual freedoms and space for them to pursue their own interests. Furthermore, with regards to the second sense of individualism as a claim about the location of moral good in the individual, it is interesting to note with Metz (2007: 333) that much of African ethics is actually individualistic insofar as it locates the good in the individual. In fact, Metz shows that the literature is dominated by individualistic interpretations of ethics: out of six, only two principles of right action he considers, base morality on some relational property; the rest base it on some individualistic consideration, be it dignity, life, utility or perfection (Metz 2007: 333). It is therefore simplistic and not obviously true to claim that African ethics is not individualistic.

Furthermore, as I pointed out, the kind of partialism defended here operates within boundaries that are permeable. This permeability implies that this partialist interpretation is not necessarily at odds with hospitality to strangers, as is commonly reported among Africans. Thus, partiality is one way of balancing personal goods, perfecting oneself, and the common good, and acting for the sake of advancing others' interests.

Is African ethics best understood in terms of impartiality as Wiredu argues? Above, I provided three salient axiological resources that suggest otherwise. I indicated that African tendency to claim that charity "begins at home" implies that when we make moral choices, we ought to put our family's good first. The idea of ancestor veneration implies that our connection with the spiritual world and God, and the possible moral goods entailed in this interaction, should be approached specifically through family channels. The idea of personhood points to the idea of partiality that one must prioritise one's project of self-perfection, achieving moral virtue, and one must work hard to take care, firstly of one's family and then, if possible, the wider community. So, this evidence undermines the impartiality thesis defended by Wiredu; moreover, it points to the direction that African ethics should be understood in terms of partiality.

\section{CONCLUSION}

In this article, I adduced three moral considerations that support partiality in the African moral tradition. To reject impartiality in the African tradition, I used Wiredu's ethical theory, sympathetic impartiality, as a foil to discuss African ethics in general. I argued that this moral principle fails to cohere with centrally defining features of African thought in general: the high price attached to the family and ancestor veneration. I also showed that impartiality is incompatible with a centrally defining feature of African moral thought, a normative concept of a person - which demands of one to live a virtuous life in a way that not everyone ends up doing. The crux of 
my argument is that the African intuitions adduced in this article support identifying African ethics with partiality rather than impartiality.

\section{REFERENCES}

Appiah, A. 1998. Ethical systems, African. Routledge Encyclopaedia of Philosophy. Edited by E. Craig. http://0-www.rep.routledge.com.ujlink.uj.ac.za:80/article/Z008SECT5 (accessed on 4 July 2009).

Behrens, K. 2011. African philosophy: Thought and practice and their contribution to environmental ethics. Johannesburg: University of Johannesburg.

Behrens, K. 2013. Two normative conceptions of personhood. Quest 25: 103-119.

Bujo, B. 2001. Foundations of an African ethic: Beyond the universal claims of Western morality. New York: The Crossroad Publishing Company.

Cottingham, J. 1981. Ethics and impartiality. Philosophical Studies 43: 8389.

Cottingham, J. 1986. Partiality, favouritism and morality. Philosophical Quarterly 36: 357-373.

Darwall, S. 1977. Two kinds of respect. Ethics 88: 36-49.

Dion, M. 2000. The moral status of non-human beings and their ecosystems. Ethics, Place and Environments 3: 221-229.

Dzobo, K. 1992. The image of man in Africa. . In Companion to African Philosophy. Edited by K. Wiredu. Oxford: Blackwell Publishing, 123-136.

Eze, O. 2005. Ubuntu: A communitarian response to liberal individualism. Pretoria: University of Pretoria.

Fayemi, A. 2010. Cultural universals and particulars in the philosophy of Kwasi Wiredu: Some comments. Thought and Practice: A Journal of the Philosophical Association of Kenya New Series 2: 19-47.

Godwin, W. 1973. Enquiry concerning political justice and its influence on general virtue and happiness. New York: Alfred A Knolf.

Gyekye, K. 1992. Person and community in African thought. In Person and community: Ghanaian philosophical studies, 1. Edited by K. Gyekye and K. Wiredu. Washington DC: Council for Research in Values and Philosophy, pp. 101-122.

Gyekye, K. 2004. Beyond cultures: Perceiving a common humanity, Ghanaian Philosophical Studies. Accra: The Ghana Academy of Arts and Sciences.

Gyekye, K. 2007. Tradition and modernity. New York: Oxford University Press.

Gyekye, K. 2010. African ethics. The Stanford Encyclopedia of Philosophy. Edited by E.N. Zalta. http://plato.stanford.edu/archives/fall2011/entries/african-ethics (accessed on 16 January 2013).

Ikuenobe, P. 2006. The idea of personhood in Chinua Achebe's Things fall apart. Philosophia Africana 9: 117-131.

Jollimore, T. 2014. Impartiality. The Stanford Encyclopedia of Philosophy. Edited by E.N. Zalta. http://plato.stanford.edu/archives/sum2011/entries/impartiality/ (accessed on 27 May 2014). 
Kagabo, L. 2004. Alexis Kagame (1912-1981): Life and thought. In Companion to African Philosophy. Edited by K. Wiredu. Oxford: Blackwell Publishing, pp. 231-242.

Kaphagawami, D. 2004. African conceptions of a person: A critical survey. In Companion to African philosophy. Edited by K. Wiredu. Oxford: Blackwell Publishing, pp. 332-442.

Liew, T. 2008. The moral limits of impartiality. Kemanusiaan 15: 41-48.

LenkaBula, P. 2008. Beyond anthropocentricity: Botho/Ubuntu and the quest for economic and ecological justice. Religion and Theology 15: 375-394.

Louw, D. 2004. Ubuntu and the challenges of multiculturalism in post-Apartheid South Africa. Utrecht: Centre for Southern Africa.

Lutz, D. 2009. African Ubuntu philosophy and global management. Journal of Business Ethics 84: 313-328.

Masolo, D.A. 2010. Self and community in a changing world. Indianapolis: Indiana University Press.

McNaughton, D. and Rawling, P. 1992. Honoring and promoting values. Ethics 102: 835-843.

Menkiti, I. 1984. Person and community in African traditional thought. In African philosophy: An introduction. Edited by A. Wright. Lanham: University Press of America, 171-181.

Menkiti, I. 2004. On the normative conception of a person. In Companion to African philosophy. Edited by K. Wiredu. Oxford: Blackwell Publishing, 324 - 331.

Metz, T. 2007. Toward an African moral theory. Journal of Political Philosophy 15: 32-341.

Metz, T. 2009. African and Western moral theories in bioethical context. Developing World Bioethics 10: 49-58.

Metz, T. 2010. Human dignity, capital punishment and an African moral theory: Toward a new philosophy of human rights. Journal of Human Rights 9: 81-99.

Metz, T. 2011. Confucianism and Ubuntu: Reflections on a dialogue between Chinese and African traditions. Journal of Chinese Philosophy 38: 78-95.

Metz, T. 2012. An African theory of moral status: A relational alternative to individualism and holism. Ethical Theory and Moral Practice: An International Forum 14: 387-402.

Musschenga, A. 2005. The debate on impartiality: An introduction. Ethical Theory and Moral Practice 8: 1-10.

Neale, P. and Paris, D. 1990. Liberalism and the communitarian critique: A guide for the perplexed. Canadian Journal of Political Science 23: 419-439.

Nkondo, G. 2007. Ubuntu as a public policy in South Africa: A conceptual framework. International Journal of African Renaissance Studies 2: 88-100.

Okeja, U. 2013. Normative justification of a global ethic: A perspective from African philosophy. New York: Lexington Books.

Oruka, H. and Juma, C. 1994. Ecophilosophy and parental earth ethics. In Philosophy, Humanity, and Ecology. Edited by H. Oruka. Nairobi, Acts Press.

Rachels, J. and Rachels, S. 2010. The Elements of moral philosophy. Boston: McGraw Hill.

Ramose, M. 1999. African Philosophy through Ubuntu. Harare: Mond Books.

Ramose, M. 2003. The ethics of Ubuntu. In The African Philosophy Reader. Edited by P. Coetzee and A. Roux. New York: Routledge, 324-33. 
Ramose, M. 2010. The death of democracy and the resurrection of timocracy. Journal of Moral Education 39: 291-303.

Shutte, A. 1993. Philosophy for Africa. Cape Town: UCT Press.

Shutte, A. 2001. Ubuntu: An ethic for a new South Africa. Pietermaritzburg: Cluster Publications.

Singer, P. 1979. Practical ethics. Cambridge: Cambridge University Press.

Warnock, G. 1971. The object of morality. London: Methuen.

Williams, B 1974. Persons, character, and morality. In Identities of Person. Edited by A. Rorty. Berkeley: University of California Press, pp. 197-217.

Wiredu, K. 1980. Philosophy and African culture. Cambridge: Cambridge University Press.

Wiredu, K. 1992. Moral foundations of an African culture. In Person and community: Ghanaian philosophical studies, 1. Edited by K. Wiredu and K. Gyekye. Washington DC: The Council for Research in Values and Philosophy, pp. 192-206.

Wiredu, K. 1996a. Cultural universals and particulars: An African perspective. Indianapolis: Indiana University Press.

Wiredu, K. 1996b. Reply to English/Hamme. Journal of Social Philosophy 27: 234-243.

Wiredu, K. 1999. Society and democracy in Africa. New Political Science 21: 33-44.

Wiredu, K. 2008. Social philosophy in postcolonial Africa: Some preliminaries concerning communalism and communitarianism. South African Journal of Philosophy 27: 332-339.

Wolf, S. 1992. Morality and impartiality. Philosophical Perspectives 6: 243-259.

Wolf, S. 1999. Morality and the view from here. The Journal of Ethics 3: 203-223. 